\title{
THE GROWTH STATUS OF QUANTITY SURVEYING FIRMS IN SOUTH-WESTERN, NIGERIA: MANAGEMENT EXECUTIVE'S PERSPECTIVE
}

\author{
Dorcas T. Moyanga ${ }^{1 *}$ and Ajoke A. Agboola ${ }^{2}$ \\ ${ }^{1,2}$ Department of Quantity Surveying, Federal University of Technology Akure, P.M.B 704, Akure, Nigeria \\ E-mail: *dorky_2001@yahoo.com
}

\begin{abstract}
Quantity surveying firms (QSFs) in Nigeria are faced with numerous challenges and stiff competitions in the construction industry that have really threatened the growth and survival of the firms. Therefore, this study examined the current growth status of QSFs in Lagos and Ondo States, Nigeria. This was achieved by assessing some germane growth indicators of firms which include asset, profit, staffing, clients and so on. Descriptive research design was adopted through a census survey of all quantity surveying firms in the study area. Questionnaires were distributed to top management executives of the firms and the data adequately analysed using analysis of variance (ANOVA) to compare the growth indicators (at startup level and current level) and test statistic $\mathrm{F}$ was computed to test hypotheses. It was revealed that QSFs have been experiencing growth in the number of employees, number of clients and asset owned by the firms. However, there is decrease in profit which is the indicator that most determines firm's growth. Therefore, the study recommends that QSFs in Nigeria should maximize their profit level so that employees' strength and salary are not affected since QSFs depends on the skill of quantity surveyors in order to succeed and survive.
\end{abstract}

Keywords : Firm growth, Growth indicators, Nigeria, Quantity surveying firms.

\section{INTRODUCTION}

The Nigerian construction industry is identified as one of the major contributors to the gross domestic product (GDP) and it is responsible for providing houses, roads and other infrastructural development for the wellbeing of the people (National Bureau of Statistics, 2015). Due to high competition for growth and survival of firms within the construction sector, firms are competing with one another and quantity surveying firms are not exempted. This competition led firms in the sector to be faced with challenges of how to remain relevant and remain in business of its field of operations. Studies abound on the challenges faced by quantity surveying in Nigeria and other developing countries (Oyediran, 2011; Ogunsemi, Awodele and Oke, 2013; Olanipekun et al., 2013; Yankah, 2015; Tunji-Olayeni, 2016; Aluthwela and Perera, 2017; Olatunji, Olawumi and Aje, 2017; Oladimeji and Adeniyi, 2017). Yet, these firms are still under pressure to offer wider range of services so as to grow and survive as a result of the rapid changes and increasing competition in the market.

Firm growth is seen as the ability of the firm to utilize and explores resources to overcome the challenges that are against them. Firm growth is a widely studied topic in many literatures and an important determinant of growth and development of an economy in terms of employment, job creation, industry concentration, to mention but a few. In the construction industry, quantity surveying firms (QSFs) are oriented organisations providing cost and value management expertise on infrastructure procurement (Olanipekun, Aje \& Abiola-Falemu, 2013). Specifically, the problem militating against the rate of growth of QSFs is due to the fact that these firms do not offer goods to be delivered to the market. In view of this, Gupta et al. (2013) asserted that the growth of a firm depends on the definition of what the firm is, how much it has grown, what assets it controls and what it offers to the market. Studies have examined the growth of construction firms in Nigeria (Bala, Bello, Kolo and Bustani, 2009; Babatunde, 2013; Odediran, Babalola and Adebiyi, 2013) but little is known to have been done to establish the growth of services/consulting firms. However, a study undertaken by Ibironke (2014) on quantity surveying 
firms' developmental stages in Nigeria examined growth determinants and developed a tool for determining the growth of quantity surveying firms though it was not validated. Hence, it is still not clear whether quantity surveying firms are experiencing growth or not and that is leading to a knowledge gap. Thus, the need for this study to examine some germane growth indicators of quantity surveying firms so as to establish the growth status of these firms in Nigeria.

\section{QUANTITY SURVEYING FIRM IN NIGERIA}

Quantity surveying firm (QSF) is a professional service sector in the construction industry that provide consultancy services and manage financial related issues for their clients (Page, Pryke and Pearson, 2004; Abidin et al., 2011). QSF employs the services of quantity surveyors and other resources to carry out quantity surveying activities. Aluthwela and Perera (2017) studied the characteristics of QSF and found out that QSF count heavily on the skills, expertise, and knowledge of QS to address clients' needs. Therefore Abidin et al. (2011) further explained that the survival and growth of the QSF depend on the number of projects they service and the securing of new projects before the one in hand ends without any intermission.

As identified by Olanipekun et al. (2014), QSF are faced with a lot of threats such as international competition, fee cutting and bidding amongst firms, professional indemnity insurance cases, conservatism and inability to change, encroachment, poor marketing and automation. Similarly, Abidin et al. (2011) noticed that there are many QSF in the industry and each is competing with one another to sustain in the industry. More so, the success of QSF is often hindered owing to having a small employee base which may affect the growth and survival of QSFs (Aluthwela and Perera, 2017). In the same vein, Masidah and Khairuddin (2005) identified that some of the professional services that the QSF render might be unnecessary and unwanted by the client, and the only way the quantity surveying profession can be attractive is to meet the expected standards of the client.

\section{GROWTH OF FIRMS}

Firm is an entity which is made up of a certain number of resources that provide the means to successfully take advantage of opportunities and grow significantly. Growth is a process that occurs whenever conditions are favorable and it is often normal and natural (Gupta et al., 2013). Despite the fact that majority of the literature used firm growth and firm survival interchangeably, (Francisco and Roberto, 2008; Kaniovski and Peneder, 2006; Gupta et al., 2013). Yet, there are literature that shows a connection between firm survival and firm growth. As observed by Carrizosa (2007), firm growth is positively correlated with the likelihood of survival and firms that experience continuous growth will have a higher probability of surviving in the market. In Ndiwa (2014)'s position, business survival is dependent on many factors and it defines how the business demonstrates that it is a workable entity and overcomes the forces (economic forces, social forces, technological advancement and legal and regulatory frameworks) that work against its existence. Similarly, Ndiwa (2014) observed that the growth of a business is considered as a survival mechanism for the business. Likewise, Jensen and Miller, 2016) affirmed that firm growth is also closely related to firm survival and it is an important determinant of income growth and economic development (Jensen and Miller, 2016). Consequently, a business that survived is said to be a growing business.

The growth of firms can be visible in a large number of ways ranging from employment growth, profit growth, customer base growth to asset growth. Firm growth as defined by Francisco and Roberto (2008) is the result of exploration of opportunities available to the firm. Similarly, Carrizosa (2007) defined firm growth as the result of a multiplicative process that affects the initial size of the firm. Robert (2009) defined firm growth in line with the classical theory of firm as a measure of change in discounted cash flow profit of the firm. According to the classical theory of firms, firms whether competitive oligopolistic or monopolistic are regarded as profit maximizers. Growth in a firm can also be defined in terms of revenue generation, value addition, and expansion in terms of volume of the business (Gupta et al., 2013). According to Ndiwa (2014), firm growth is a complex concept and takes two broad forms namely; organic growth and inorganic growth. The former being increase in overall customer base, output per customer and sales while the latter can be seen when the firm changes through mergers, acquisitions or takeovers. To establish the growth of quantity surveying firm, the change in some germane characteristics or variable of the firm was analysed. In order to further establish the growth status of quantity surveying firms in Nigeria, the following null hypotheses were formulated. 


\section{INDICATORS OF FIRM'S GROWTH}

Winders and Malizia (2001) posited that firm size, age, ownership, industry and region are important indicators of the growth and survival of a business. There are a vast number of possible indicators of firm growth and most commonly, employment and total sales, which reflect the size of the firm and sometimes asset growth are used as firm growth indicator (Coad and Hölzl, 2010). Rates of growth of sales, employment and productivity appear to be the most reliable indicators for evaluation of inter-firm differences. Sequel to this, null hypotheses was formulated in this study to determine if quantity surveying firms in Nigeria are growing in term of employment and assets. The hypotheses are;

H01: There is no significance difference in the startup size and current size of quantity surveying firms,

H02: There is no significance difference in the startup asset and current asset of quantity surveying firm.

Other indicators of firm growth, as identified by Carrizosa (2007), include financial or stock market value, number of employees, sales and revenue, productive capacity, value of production, added value of production, employment rate and firms' asset. In the same vein, However, Hassan et al. (2007) identified three dimensions of quantity surveying firms' growth, which are profit growth, increase in manpower and increase in number of diversified clients. In this study, the growth of quantity surveying firm in terms of profit and numbers of clients will be tested using a null hypotheses, as presented below;

H03: There is no significance difference in the startup number of client and current number of client of quantity surveying firm,

H04: There is no significance difference in the startup profit and current profit of quantity surveying firm,

Summarily, the indicators of firm growth includes, size of the firm, age of the firm, profit or productivity of the firm, assets of the firm, customer or client, firms' ownership. Table 1 shows the summarized review of the literature on growth indicators/determinants.

Table 1: Indicators of QSFs Growth

\begin{tabular}{|c|c|c|}
\hline Growth Indicators & Measurement & Author \\
\hline Firm's Size & Number of Employee & $\begin{array}{l}\text { Baron and Spulber, 2017; Blandina and Adelino, 2004; } \\
\text { Carrizosa, 2007; Coad and Hölzl, 2010; Fadhlin, 2004; } \\
\text { Francisco and Roberto, 2008; Hassan et al., 2007; Jonas and } \\
\text { Donald, 2015; Margherita and Alessandro, 2007; Nurulhasanah } \\
\text { et al., 2015; OECD 2003; Smith, 2005. }\end{array}$ \\
\hline Firm's Client & $\begin{array}{l}\text { Number } \\
\text { Clients/Contractors }\end{array}$ & Abidin et al., 2011; Hassan et al., 2007; Smith 2005. \\
\hline Firm's Profit & $\begin{array}{l}\text { Amount left-over After } \\
\text { Deducting Running and } \\
\text { Overhead Charges (In } \\
\text { Millions) }\end{array}$ & $\begin{array}{l}\text { Carrizosa, 2007; Dunne and Masenyetse, 2015; Francisco and } \\
\text { Roberto, 2008; Oke, Aigbavboa and Thwala, } 2016 .\end{array}$ \\
\hline Firm's Asset & $\begin{array}{lll}\text { Asset } & \text { Worth } & \text { (In } \\
\text { Millions) } & \end{array}$ & Carrizosa, 2007; Ndiwa 2014; Setiadharma and Machali, 2017. \\
\hline Firm's Age & $\begin{array}{l}\text { Number of Years in } \\
\text { Existence }\end{array}$ & $\begin{array}{l}\text { Blandina and Adelino, } 2004 \\
\text { Dunne and Masenyetse, 2015; OECD, } 2003 .\end{array}$ \\
\hline Firm’s Ownership & Number of Partners & $\begin{array}{l}\text { Dunne and Masenyetse, 2015; Mata and Portugal, 1994; Oke et } \\
\text { al., } 2016 .\end{array}$ \\
\hline Firm's Origin & Country of Origin & Dunne and Masenyetse, 2015; Youseline and Johanna, 2016. \\
\hline
\end{tabular}




\section{MATERIALS AND METHODS}

This study adopted a descriptive research design since the study is concerned with describing the characteristics of firms and determining the frequency at, which they associate with each (Kothari and Garg, 2014). A semi-structured questionnaire was designed to collect primary data from quantity surveying firms (QSFs) in South-western, Nigeria. Principal partners or senior quantity surveyors from the Seventy-one (71) firms registered with the Nigerian Institute of Quantity Surveyors (NIQS) in Lagos and Ondo States were contacted to obtain information required to achieve the objective. This is so because top management is in best position to provide relevant information about the firm. Also, the study ensured that only one questionnaire was administered per firm in order to eliminate double entry of information. In order to establish that the firms have been experiencing growth, analysis of variance (ANOVA) was used to compare the mean scores of the growth indicators (at startup level and at current level). The test statistic F was computed and compared with the tabulated value of $\mathrm{F}$ at two different degrees of freedom (df). The decision rule states that if the value of $\mathrm{F}$ calculated is greater than the table value of F, then the null hypothesis Ho should be rejected. That is, if Fcal $>$ Ftab, then reject Ho, otherwise accept. In addition, cronbach alpha coefficient was carried out to determine the reliability of the questionnaire. The alpha value of 0.881 depicts that the research instrument is reliable since Pallant (2005) suggested that a research instrument is reliable if the alpha value is above 0.70 .

Out of the 71 questionnaires that were administered to top management of each quantity surveying firms, 41 were retrieved representing a response rate of 57.75\%. According to Baruch (as cited in Owusu-Manu et al. (2017), a response rate of approximately 35 per cent is satisfactory for most academic studies targeting top management or organizations' representatives. This implies that the responses obtained for this study are suitable and acceptable.

\section{RESULTS AND DISCUSSIONS}

Based on the analysis of the background information of the respondents, the result shows that $46.3 \%$ of the respondents are principal partners while $53.7 \%$ are senior quantity surveyors. $4.90 \%$ of the respondents are FNIQS, $83.40 \%$ are MNIQS while $11.60 \%$ are probationer members. Also, the respondents have an average of 13 years of experience which implied that they have sufficient experience to respond to the questionnaire.

\subsection{Growth indicators of Quantity Surveying Firms}

The result on Table 2 shows that most QSFs have less than 10 employees working within the firm and that implies that majority of QSFs are micro-sized firms. The finding of this study is in contrast with the findings of Smith (2005), Hassan et. al. (2007), Ibironke (2014) and, Jonas and Donald (2015), that most QSFs are smallsized. Also in contrast to the study, is the finding of Fadhlin (2004), which stated that most QSFs are mediumsized firms. Also, most of the QSFs have their profit and assets (excluding landed property) between one and five Million, which further indicates that they are micro-sized firms and seems not to be growing.

Also, majority of the QSFs examined under this study have been in existence for about 13 years which implies that quantity surveying firms are matured firms. This is in line with the classification of firms by Dunne and Masenyetse (2015) that a young firm is less than 5 years while a middle aged firm is between the ages of 5 and 10 years, and a mature firm is the one with the age greater than 10 years. Furthermore, the findings also revealed that all the QSFs under this study are indigenous and originated from Nigeria, implying that all the firms are owned by Nigerians and they all have equal chances of growth. 
Table 2: Growth Indicators of QSFs

\begin{tabular}{|c|c|c|c|}
\hline & Classification & Frequency & Percent \\
\hline \multirow{5}{*}{ Current size (number of employee) } & $1-5$ & 19 & 46.30 \\
\hline & $6-10$ & 7 & 17.10 \\
\hline & $11-15$ & 12 & 30.00 \\
\hline & $16-20$ & 3 & 7.50 \\
\hline & Total & 41 & 100 \\
\hline \multirow{5}{*}{ Current number of client } & $1-5$ & 3 & 7.50 \\
\hline & $6-10$ & 15 & 37.50 \\
\hline & $11-15$ & 8 & 17.50 \\
\hline & $16-20$ & 15 & 37.50 \\
\hline & Total & 41 & 100 \\
\hline \multirow{5}{*}{ Current profit (in millions) } & Not sure & 15 & 36.58 \\
\hline & $1-5$ & 13 & 31.71 \\
\hline & $6-10$ & 9 & 21.95 \\
\hline & $11-15$ & 4 & 9.76 \\
\hline & Total & 41 & 100 \\
\hline \multirow{5}{*}{$\begin{array}{l}\text { Current value of asset (in millions) } \\
\text { excluding landed properties }\end{array}$} & Not sure & 13 & 31.71 \\
\hline & $1-5$ & 11 & 26.83 \\
\hline & $6-10$ & 9 & 21.95 \\
\hline & $11-15$ & 8 & 19.51 \\
\hline & Total & 41 & 100 \\
\hline \multirow{6}{*}{ Firm's age (in years) } & $1-5$ & 9 & 21.95 \\
\hline & $6-10$ & 8 & 19.51 \\
\hline & $11-15$ & 8 & 19.51 \\
\hline & $16-20$ & 7 & 17.08 \\
\hline & $21-25$ & 9 & 21.95 \\
\hline & Average & 12.88 & 100 \\
\hline \multirow{6}{*}{ Number of partners } & Nil & 11 & 26.84 \\
\hline & 1 & 9 & 21.95 \\
\hline & 2 & 6 & 14.63 \\
\hline & 3 & 7 & 17.07 \\
\hline & 4 & 8 & 19.51 \\
\hline & Total & 41 & 100 \\
\hline \multirow{3}{*}{ Firm'Origin } & Local & 41 & 100 \\
\hline & Foreign & 0 & 0.00 \\
\hline & Total & 41 & 100 \\
\hline \multirow{4}{*}{ Firm's ownership } & Sole Proprietorship & 20 & 48.80 \\
\hline & Partnership & 15 & 36.60 \\
\hline & Consortium & 6 & 14.60 \\
\hline & Total & 41 & 100 \\
\hline
\end{tabular}

\subsection{Growth of Quantity Surveying Firm (QSF): Hypotheses Testing}

The Table 4 shows the result of the analysis of the growth indicators of quantity surveying firms. This analysis was carried out in order to test the hypotheses and establish that quantity surveying firms have been experiencing slight growth. The growth indicator consists of four variables which are the size of the firm, number of clients, profit of the firm and asset owned by the firm. The data were collected at two different levels, at the startup level and current level of the firm.

For the startup size and current size, the null hypothesis H01 was rejected because the computed value of F (20.481) was higher than the table value of F (2.84) at 5\% significance level. This implies that there is a 
significant difference in startup size of QSFs and current size of QSFs. Thus, alternative hypothesis was accepted. Most QSFs only employs few people at the start of the business and then gradually increases as time goes on. Increase in size or increasing number of employee is an indication that the firm is growing. In other words, QSFs have been experiencing growth in terms of size which corroborates the finding of Hassan et al. (2007) that increase in staffing/employment (size) is one of the three major components that determine the growth of quantity surveying firm. For the startup and current number of client, Fcal (15.909) is greater than the Ftab (2.87), thus the null hypothesis H02 was rejected. There is always an increase in the demand for QS services by the clients. This implies that the number of QSFs client at startup is not the same as the current number of clients of QSFs. Thus, indicating the growth of QSFs in terms of increase in client. Findings revealed that QSFs have been experiencing growth in number of client. This is also in line with the findings of Hassan et al., 2007). Growth in asset owned by QSFs is also a finding of the study. This finding is slightly in contrast to the findings of Ogunsemi et al. (2013) that quantity surveying firms are not growing and adequately managed because it is difficult to secure job commissions from clients. The third null hypothesis $\mathrm{H} 03$ was accepted because the computed value of $\mathrm{F}(0.747)$ was lesser than the table value (2.84) and the significance level (0.608). This shows that there is no difference in the profit level of QSFs at the startup level and current level. The fourth category, null hypothesis H04 was also rejected because the value of Fcal (16.673) was higher than the table value (2.87) at 3 and 35 degree of freedom. This means that there is a difference between the startup asset and current asset of QSFs.

Table 3: Growth of QSFs

\begin{tabular}{|c|c|c|c|c|c|c|c|}
\hline \multicolumn{8}{|c|}{ ANOVA Table } \\
\hline & & Df & Mean Square & Fcal & Ftab@5\% & Sig. & Decision \\
\hline \multirow{2}{*}{$\begin{array}{l}\text { Startup size * Current } \\
\text { size }\end{array}$} & $\begin{array}{l}\text { Between Groups } \\
\text { (Combined) }\end{array}$ & 3 & 2.405 & 20.481 & 2.84 & 0.000 & Rejected \\
\hline & Within Groups & 37 & 0.117 & & & & \\
\hline \multirow{2}{*}{$\begin{array}{l}\text { Clients at start up * } \\
\text { Current number of } \\
\text { client }\end{array}$} & $\begin{array}{l}\begin{array}{l}\text { Between Groups } \\
\text { (Combined) }\end{array} \\
\end{array}$ & 3 & 0.769 & 15.909 & 2.87 & 0.000 & Rejected \\
\hline & Within Groups & 35 & 0.048 & & & & \\
\hline \multirow{2}{*}{$\begin{array}{l}\text { Startup profit * } \\
\text { Current profit }\end{array}$} & $\begin{array}{l}\text { Between Groups } \\
\text { (Combined) }\end{array}$ & 3 & 0.404 & 0.747 & 2.84 & 0.531 & Accepted \\
\hline & Within Groups & 37 & 0.541 & & & & \\
\hline \multirow[t]{2}{*}{$\begin{array}{l}\text { Startup asset } * \text { Current } \\
\text { value of asset }\end{array}$} & $\begin{array}{l}\text { Between Groups } \\
\text { (Combined) }\end{array}$ & 3 & 1.557 & 16.373 & 2.87 & 0.000 & Rejected \\
\hline & Within Groups & 35 & 0.095 & & & & \\
\hline
\end{tabular}

\section{CONCLUSIONS}

The study assesses the growth of quantity surveying firms in South-western, Nigeria by investigated the growth indicators of these firms so as to ascertain their growth status. From the finding, QSFs in Nigeria are growing which is evident in the increasing number of employee, number of clients and asset owned. However, the majority of these QSFs are not profitable as expected though they are at their maturity stage. Hence, the implication is that the financing of QSFs is impeded and the study therefore suggest that the management of the firms should devise ways of maximize their profit level so as to ensure that employees' strength is not affected and that the firm survive the changing demands in the construction industry.

The study was limited to the States in South-west region of Nigeria. To further ascertain the growth status of quantity surveying firms in other geo-political regions, the study should be replicated and extended to these regions. 


\section{REFERENCES}

Abidin, N. Z., Yusof, N., Hassan, H., Adros, N. A. (2011). Applying competitive strategy in quantity surveying firms: An evolving process. Asian Journal of Management Research, 2 (1): 61-73.

Aluthwela, A. \& Perera, B. A. K. (2017). Characteristics of quantity surveying firms and their impact on performance.

Babatunde, O. K. (2013). Chinese Construction Firms in the Nigerian Construction Industry. Habitat International, 40: 18-24.

Bala, K., Bello, A., Kolo, B.A., Bustani, S.A. (2009). Factors inhibiting the growth of local construction firms in Nigeria. In: Dainty, A. (Ed) Procs 25th Annual ARCOM Conference, 7-9 September 2009, Nottingham, UK, Association of Researchers in Construction Management, 351-359.

Baron, J., Spulber, D. F. (2017). The effect of technological change on firm survival and growth - evidence from technology standards.

Blandina, O., Adelino, F. (2004). Determinants of firm growth: a comparative study between a panel of portuguese manufacturing and services firms? Prepared for presentation at the Thirty-first 31st conference of the European Association for Research in Industrial Economics, 1-20. Berlin.

Carrizosa, M.T. (2007). Firm growth, persistence and multiplicity of equilibria: an analysis of spanish manufacturing and service industries. Virgili, Spain: Universitat Rovira I Virgili.

Coad, A., Hölzl, W. (2010). Firm growth: empirical analysis. (M. J. Evolutionary Economics Group, Ed.) Economics and Evolution: 1-24.

Dunne, P. J., Masenyetse, R. (2015). The determinants of firm survival in South Africa. Paper prepared for the Economic Society of South Africa (ESSA) biennial conference 2-24. South Africa.

Esteve-Pérez, S., Pieri, F., Rodríguez, D. (2013). Innovation, growth and survival of Spanish manufacturing firms. Universitat de València, Department of Applied Economics II.

Fadhlin, A. (2005). Preliminary findings of the research on the profile of the quantity surveying practice in Malaysia. Proceedings in QS National Convention, Kuala Lumpur, Malaysia.

Francisco, D. H., Roberto, V. (2008). The determinants of firm's growth: an empirical examination.

Gupta, P. D., Guha, S., Krishnaswami, S.S. (2013). Firm growth and its determinants: Journal of Innovation and Entrepreneurship 2(15): 1-14.

Hassan, H., Rahmat, H. I., Ali, S. A. (2007). Strategic planning for quantity surveying firms. Proceeding of the Quantity Surveying International Convention: Enhancing and empowering the profession. Malaysia.

Ibironke, O. T. (2014). Assessment of Development Pattern and Performance of Quantity Surveying Firms in Lagos State, Nigeria. Doctoral Research Thesis (Unpublished). Submitted to the School of Postgraduate Studies, Federal University of Technology Akure.

Jensen, R., Miller, N. (2016). Informaton, demand and the growth of firms:evidence from a natural experiment in India. Kerala.

Jonas, E. Y., Donald, K. D. (2015). Push and pull factors of innovation performance in quantity surveying firms. Journal of Economics and Sustainable Development, 6 (20): 188-196. 
Kaniovski, S., Peneder, M. (2006). Determinants of Firm Survival: A Duration Analysis using the generalized Gamma distribution. Vienna, Austria.

Kothari, C.R. \& Garg G. (2014). Research Methodology: Methods and Techniques. 3rd Ed. New Age International Publishers, New Delhi.

Margherita, V., Alessandro, V. (2007). Firms' survival and competitiveness: a case study in Tuscany. Statistica Applicata, 19 (4): 325-342.

Masidah, A., Khairuddin, A. (2005). Expectation of clients, architects and engineers on the roles and functions of quantity surveyors in relation to cost control of building projects. Proceedings of the Quantity Surveyors' (Biennial) Convention. University of Malaysia, Malaysia, 19-29.

Mata, J., Portugal, P. (1994). Life duration of new firms. The Journal of Industrial Economics, 42 (3): 227-245.

Ndiwa, H. K. (2014). The effect of innovation and technology management practices on business survival in the motor vehicle industry in Kenya. (Master's thesis) University of Nairobi, Kenya.

Nigerian Institute of Quantity Surveyors (NIQS). (2016). Nigeria institute of quantity surveying firms. Retrieved from: http://niqs.org.ng/niqs-firms/

Nurulhasanah, A. R., Zulnaidi, Y., Rafisah, M. R. (2015, August11-15). An overview of technological innovation on SME survival: a conceptual paper. Presented at the Sixth International Research Symposium in Service Management, Kuching, Malaysia.

Odediran, S. J., Babalola, M. O., Adebiyi, H. A. (2013). Assessment of Business Development Strategies in the Nigerian Construction Industry. Journal of Business \& Management, 2(1): 34-45.

Ogunsemi, D.R., Awodele, O.A., Oke, A.E. (2013). An Examination of the management of quantity surveying firms in Nigeria. Annual Conference of Registered Quantity Surveyors. Abuja.

Oke, A., Aigbavboa, C., Thwala, W. (2016). Personnel management practices in Nigerian quantity surveying firms. Journal of Construction Project Management and Innovation , 6 (1): 1651-1663.

Oladimeji, A. B., Adeniyi, H. O. (2017). An Appraisal of Quantity Surveying Profession in the Nigerian Construction Industry. International Journal of Sciences, Engineering and Environmental Technology, 2 (1): $1-9$

Olanipekun, A. O., Aje, I. O., Abiola-Falemu, J. O. (2013). Effects of Organisational Culture on the Performance of Quantity Surveying Firms in Nigeria. International Journal of Humanities and Social Science, 3 (5): 206-215.

Olanipekun, A. O., Ibironke, O. T., Awodele, O. A., Ogunyemi, T. I. (2014). Competitive strategies of selected quantity surveying firms in Nigeria. International Journal of Management, Information Technology and Engineering, 2 (11): 1-18.

Olatunji, S. O, Olawumi, T. O., Aje, I. O. (2017). Rethinking Partnering among Quantity Surveying Firm in Nigeria. Journal of Construction Engineering and Management, 143 (11): 112.

Organization for Economic Co-operation and Development (OECD). (2003). High-growth SMEs and employment. Retrieved from www.oecd.org.

Owusu-Manu, D., Torku, A., Parn, E., Addy, M.N., Edwards, D.J. (2017). An empirical assessment of innovation practices of quantity surveying firms in Ghana. Journal of Construction Project Management and Innovation, 7(1): 1843-1858. 
Oyediran, O. S. (2011). Challenges to the Efficient Service Delivery by Quantity Surveyors. A Paper presented at the 2011 Quantity Surveying Assembly and Colloquium, theme: 'Quantity Surveying and the AntiCorruption Crusade-Achieving Value for Money in Project Costs in Nigeria' held at Shehu Musa Yar'Adua Centre, Abuja, Nigeria on 28th-29th September.

Page, M., Pearson, S., Pryke, S. (2004). Innovation and current practice in large UK quantity surveying firms. RICS Foundation Publications, 4(26): 1-19.

Pallant, J. (2005). SPSS Survival Manual: A Step Guide to Data Analysis Using SPSS for Windows (Version 12). $2^{\text {nd }}$ Edition, Allen and Unwin, Crows Nest NSW 2065, Australia.

Robert, C. (2009). Determinants of small firm survival and growth. The Oxford Handbook of Entrepreneurship, ed. By Basu, A., Casson, M., Wadeson, N. and Yeung, B., 161-193. Oxford University Press.

Setiadharma, S., Machali, M. (2017). The effect of asset structure and firm size on firm value with capital structure as intervening variable. Journal of Business \& Financial Affairs, 6 (4): 1-5.

Smith, P. (2005). Trends in the utilization of automated quantities by the Australian quantity surveying profession: 1995-2005. University of Technology, Sydney, Australia.

Tunji-Olayeni, P. (2016). Performance, challenges, and prospects for the professional in a global economic recession. Paper presented at the 2-Day Workshop and Investiture of the 2016/2018 Senate Members of NIQS held in Ibadan, Oyo State.

Winders, R.M., Malizia E. E. (2001). Survival and growth of young firms. TVA Rural Studies Program/ Contractor Paper, 1-14.

Yankah, J. E. (2015). Marketing Performance of Quantity Surveying Consultancy Firms. International Journal of Construction Engineering and Management, 4(6): 230-237.

Youseline, G. H. \& Johanna, M. U. B. (2016). Analysis of the determinants of firm's survival. (Doctoral dissertation, Universitaria de Investigacion Desarrollo, (UDI) 